\title{
THE ATTORNEY GENERAL OF ENGLAND AND THE ATTORNEY GENERAL OF THE UNITED STATES*
}

\author{
Robert Kramerif and Nathan Siegel
}

\begin{abstract}
A LMOST thirty years ago, Mr. Justice Cardozo, one of America's most distinguished scholars and judges, in an address of welcome to the English bench and bar, said: ${ }^{1}$

No strangers these at all but kinsmen of the blood who have kept alive traditions of learning, of honor, of courage, of devotion, that were born long ago when their law was one with ours.
\end{abstract}

The passage of time has not altered this apt description. For, as all the world knows, when it comes to law and ordered liberty, English and American tradition, ideals, and principles are bound as one. And, it is, therefore, not at all strange that the title and office of the Attorney General of the United States also have their origin in the office of the English Attorney General.

The title of "Attorney General" was one designated by the First Congress of the United States, which in 1789 passed the Judiciary Act creating such an office in this country. ${ }^{2}$ But this title was not original

* This paper is based on one prepared for delivery by Mr. Kramer before visiting members of the English bar at the annual meeting of the American Bar Association, at Washington, D.C., in August 1960. The views expressed herein are those of the writers and do not necessarily reflect those of any agency or department of the federal government. Mr. Siegel had the laboring oar in the preparation of this paper. The writers wish to express their gratitude to Mr. J. L. Simpson of the United Kingdom Mission to the United Nations, who made many helpful suggestions after reading an early draft of this paper.

$\dagger$ A.B. 1935, LL.B. 1938, Harvard University. Member of the District of Colunbia and New York bars; Professor of Law, Duke University (on leave); Assistant Attorney General, Office of Legal Counsel, United States Department of Justice. Author [with Charles L. B. Lowndes], Federal Estate and Gift Taxation (1956). Contributor to legal periodicals.

$\$$ A.B. 1932, College of the City of New York; J.D. 1934, New York University. Member of the New York bar; Attorney, Office of Legal Counsel, United States Department of Justice. Contributor to legal periodicals.

${ }^{2}$ Quoted in Goodhart, English Contributions to the Philosophy of LaW it (r948).

${ }^{3}$ Key, The Legal Work of the Federal Government, 25 VA. L. REv. 165, 166 (1938). 
with Americans. Legal officers known by that name had long existed in England-and for that matter, in all the colonies before the American Revolution. By the time the First Congress met, officers bearing the title "Attorney General" were already recognized as having authority over the legal affairs of the colonial governments they served. ${ }^{3}$

As a rule, these officers became possessed with the common-law powers and duties of the English Attorney General, except as changed by specific statute or constitution. Consistent with the doctrine of separation of powers which took root here at an early time, several state constitutions expressly provided that the Attorney General should not sit in the legislature. Thus, for example, in Massachusetts, the Attorney General, while holding the office, was forbidden to sit in the House of Representatives; ${ }^{4}$ in North Carolina, he was barred from having a seat in the Senate, House of Commons, or Council of State ${ }^{5}$ and in Pennsylvania, he could not sit in the General Assembly, Executive Council, or Continental Congress. ${ }^{6}$ Thus, it was generally recognized that the Attorney General was an officer of the executive branch, in most cases to be appointed by the Governor with the advice and consent of the legislative body. ${ }^{7}$

When the bill for creation of the office as "Attorney General" was introduced in the First Congress, provision was initially made for his appointment by the courts, but prior to passage, the bill underwent an important change authorizing the President to make the appointment, and this has been the law ever since. ${ }^{8}$

Today, the Attorney General of the United States is a member of the Cabinet. But when the nation was established in I789, Edmund Randolph, the first Attorney General, for one reason or another, but more probably because he was too immersed in his private affairs, did not sit with the Cabinet. ${ }^{9}$ Within several years, however, problems coming before the Cabinet increasingly involved questions of law requiring more frequent attendance of the Attorney General. ${ }^{10}$ Even so, it was not until President Madison's second term in I8I4 that Congress

s $I d$.

- Hammonds, The Attorney General in the American Colonies, i, 7 (New York University Law School, Anglo-American Legal History Series, No. I, 1939).

${ }^{5} I d$. at $\mathrm{I} 3$.

${ }^{8} I d$. at 15 .

'Id. at 2-22.

${ }^{8} I d$. at 23 .

${ }^{\circ}$ Cummings \& McFarland, Federal Justice 26 (i 937 ).

${ }^{10} \mathrm{Id}$. 
passed an act requiring the Attorney General from that time to reside in Washington, and this step led to his more complete identification with the Cabinet. ${ }^{11}$

Despite his increased prestige, the office of the Attorney General for about eighty years after its establishment was maintained by a small staff on a modest budget. The Attorney General exercised little jurisdiction over United States attorneys and marshals, and the several departments had gradually developed their own law officers who took as little counsel as possible from the Attorney General and paid substantial sums for special counsel in cases arising within their own jurisdiction. Through a drastic reform bill enacted in 1870 , the Department of Justice came into being, with the Attorney General as its head. ${ }^{12}$ With sweeping powers, government litigation previously conducted by various departments was now lodged in the Attorney General. He was to be aided by a Solicitor General - a title known to England since the fifteenth century-and by Assistants to the Attorney General. Since then, keeping pace with the needs of the nation, the Department of Justice has grown considerably. At present, the Attorney General administers an organization of 1700 attorneys and a total of 30,000 employees, dispersed in eleven buildings in Washington and in 500 additional offices throughout the United States and its territories.

Consider for a moment, the variety of the Justice Department's day-to-day operations. In a single day the Attorney General may be called on to do some or all of these things:

To advise the President whether to veto a bill because it may be contrary to the Constitution; to initiate antitrust proceedings to break up a merger of giant institutions whose aim is to restrict competition; to request a grand jury indictment where bombings endanger civil liberties; to seek an injunction in a paralyzing public emergency strike; to start deportation proceedings against a leading racketeer who has abused the privilege of living here; to bring to justice an espionage agent; to settle claims brought as a result of a service plane crash with a commercial airliner; to try some politicians who peddled their influence in the Government; to defend against the claims of an Indian tribe for land taken from it.

Generally, the Attorney General's functions fall into several major areas. First, he renders legal advice to the President, Cabinet members, and officials of other agencies within the Federal Government.

\footnotetext{
${ }^{11} 2$ KENNEDY, MEMOIRS OF THE LIFE OF WILLIAM WIRT 54 (1850).

${ }^{12}$ Cummings \& MCFARLAND, op. cit. supra note 9, at 225.
} 
Second, he enforces the federal criminal and civil laws. Third, he administers various federal programs such as prisons, parole, immigration and naturalization, and alien property.

Just as it is one of the principal functions of the Attorney General of England to give advice, when requested, to the government departments on legal questions of exceptional diffculty or importance, ${ }^{13}$ so too, of the numerous functions performed by the Attorney General of the United States, none is more important than giving legal advice to the President and heads of departments. In this connection, the Attorney General is assisted by the Office of Legal Counsel. Its small group of lawyers, numbering fewer than twenty, rarely appear in court. Their field of knowledge must include constitutional, international, administrative, and other fields of law and also a mature familiarity with the work, operation, and interrelationships between the Congress, the courts, and the executive departments and agencies. In brief, the entire exposition and defense of the President's powers under the Constitution and laws of the United States fall upon the Attorney General.

In order properly and effectively to carry out his functions, it became necessary at an early day for the Attorney General to restrict the giving of legal advice solely to those specifically authorized to receive it by statute, viz., the President and heads of departments. This required the Attorney General to refuse to render official opinions not only to individual citizens, but even to the Congress, congressional committees, and individual members of Congress. Typical of requests for opinions in early days was one from a firm of shipowners who inquired whether the law relating to seamen would apply to a member of the crew who one morning was taken sick "by which it was discovered he was a female. ${ }^{14}$

The opinions of the Attorney General, prepared in the Office of Legal Counsel, appear in two forms: published and unpublished. The practice of publishing opinions of the Attorneys General, started in I84I, ${ }^{15}$ has produced an important collection of legal and constitutional

${ }^{13}$ Chester \& Willson, The Organization of Central Government I9141956, at 135 (1957); WADE \& Phillips, Constitutional LaW I73 (5th ed. 1955); KEITH, THE BRITISh CABINET SYSTEM 1830-1938, at 244 (1939).

14 CUMmings \& MCFARLAND, op. cit. supra note 9, at 88.

${ }^{15}$ Ibid.; Learned, The Attorney General and the Cabinet, 24 PoL. Scr. Q. 444, 451 (1909). It would appear that opinions of the Law Officers of the Crown are given confidential treatment. Contrast Between Duties of Attomey General of the United States and Those of the Law Officers of the British Crown, $3^{8}$ AM. L. REv. 924 (1904). 
precedents in this country. One written in 1940 involved the authority of the President, as Commander-in-Chief, to transfer fifty reconditioned destroyers to England in return for the lease of certain British naval bases. ${ }^{16}$ Sometimes opinions are requested and written to resolve a conflict among various departments. In one unique case, there was sharp diversity of views about the much mooted question under the pure food laws "What is whiskey?" Breaking precedent, President Taft himself wrote the opinion.

Other opinions, less dramatic but equally important, have related to the President's various constitutional functions as Administrative Chief, as Chief Executive, and as the "Sole Organ of Foreign Relations" in sundry matters such as:

The right of the President to dismiss a chief subordinate who has been confirmed by the Senate-

The right of the President to delegate certain of his powers-

The scope of the President's authority in making executive agreements with foreign nations-

The right of the President to withhold confidential papers and documents from congressional committees.

Now how do the office of Attorney General of England and the Attorney General of the United States compare in other respects?

The Office of Attorney General of England has no statutory basis. ${ }^{17}$ $\mathrm{He}$ is appointed by the Crown on the recommendation of the Prime Minister. The Attorney General of England usually is not a member of the Cabinet. ${ }^{18}$ It appears, however, that the Attorney General is always available to advise the Cabinet on the legal aspects of any matter that is being submitted to it, and he may be requested to attend meetings of the Cabinet. ${ }^{10}$

The Attorney General of the United States, whose office is created by statute, is appointed by the President, with the advice and consent of the Senate. As has been observed, he is a member of the Cabinet. Being a presidential appointee within the executive branch, the tenure of the Attorney General is dependent upon the pleasure of the President. As in England, the Attorney General of the United States normally

\footnotetext{
${ }^{26}$ Corwin, The President: Office and Powers 238 (1957).

${ }^{17}$ Keeton, A Liberal Attorney General 138 (1949); See too 6 Holdsworth, HISTORY OF ENGLISH LAW 458-8x (x924).

${ }^{18} I d$. at ${ }^{136}$. Sir Isaacs and Sir Hogg were exceptions to the general rule. KEITH, op. cit. supra note $3_{3}$.

${ }^{10}$ Jennings, Cabinet Government 232 (1959).
} 
would be replaced upon a change of administration. Once the appointment is confirmed, however, the Attorney General is answerable to the President alone and subject to removal by him alone. While the Attorney General of England usually approaches the Sovereign through the Lord Chancellor or a Secretary of State, ${ }^{20}$ the Attorney General of the United States not only has direct access to the President, but often in our history has been one of the President's closest advisers. ${ }^{21}$

Perhaps the greatest difference between the two offices is with respect to their relationship to the legislative branch of the Government. Under our theory of separation of the executive, judicial, and legislative branches, the Attorney General of the United States-a member of the executive branch-is not in any way identified with the Congress-the legislative branch. On the other hand, not only is the English Attorney General generally a member of the House of Commons, but it is also one of his important functions to reply in the. House of Commons to questions relating to legal matters or matters within the province of the Lord Chancellor's Department. ${ }^{22}$

How did it happen that the Attorney General of England was early drawn into Parliament? History shows that it was a matter of regal expedience. The Crown found it necessary to rely on law officers who possessed not only legal learning, but also political acumen in fighting constitutional battles against such seasoned veterans as Pym, Hampden, and other parliamentarians. ${ }^{23}$

One need only read the debates to understand what a searching cross-examination the Attorney General of England may be subjected to on the floor of the House of Commons when he attempts to defend the validity of an administration measure over hostile opposition. ${ }^{24}$ While the Attorney General of the United States has no comparable status, nor an opportunity to engage in floor debates in the Congress, he may well be called on to draft legislation, and he often appears by invitation before a committee of either House of Congress to testify on legislative matters. And on some of these occasions-as for example

${ }^{30}$ KEETON, op. cit. supra note 17 , at $14 \mathrm{I}$.

${ }^{21}$ See, e.g., 2 Fuess, Caleb Cushing 137 (1923); James, Richard Olney 3 (1923).

${ }^{23}$ KeETON, op. cit. supra note 17 , at 142 .

${ }^{23} I d$. at 129 .

${ }^{24}$ See, e.g., Great Britain Parliamentary Debates, Commons 207, May 30, 1927 to June 24, 1927, on Trade Disputes and Trade Union Bill. Library of Congress I 303.H.6. 
during hearings held recently on the Civil Rights Bill-the Attorney General may be subjected to very intense cross-examination by committee members.

The English Attorney General is available for consultation by Parliamentary Counsel, the official responsible for the drafting of all government bills, and the Attorney General or the Solicitor General will nearly always be in his place on the Government Front Bench when the House of Commons is debating a bill that raises intricate legal issues. The close relationship of the English Attorney General to Parliament is also shown by the fact that he acts as prosecutor both for the House of Lords and the House of Commons. ${ }^{25}$ Although the United States Attorney General has no such specific function, he does supervise and direct the defense of actions brought against officers of either House of Congress for their official acts. In addition, if a witness refuses to cooperate with the Congress, or is otherwise in contempt of its process, the Attorney General, upon request of either House, may bring criminal prosecution against the contumacious witness in order to vindicate the congressional authority and enable it to carry out its legislative functions.

What are the differences in the performance of duties so far as judicial proceedings are concerned?

Generally, it has been said that the Attorney General of England has the ultimate responsibility of all litigation to which the Crown or a government department is a party, ${ }^{26}$ and much of this litigation is brought or defended in the name of the Attorney General. Although he has merely a small professional staff to assist him, he appoints junior counsel of government departments and may nominate counsel to appear for the Crown in any cases, civil or criminal. ${ }^{27} \mathrm{He}$ is also the proper party to take action where a judge has been personally abused and to defend where high officials in government are challenged in the discharge of their duties. ${ }^{28} \mathrm{He}$ may personally conduct the prosecution in cases of great public interest. ${ }^{29}$

However, the administration of the criminal law, public order, and other matters of public safety are generally under the Home Office. ${ }^{30}$

\footnotetext{
${ }^{25} 7$ HaLsBURY, LAWS OF ENGLAND 383 (3d ed. 1954).

${ }^{20} \mathrm{KEETON}$, op. cit. supra note 17 , at 140; CHEsTER \& Willson, op. cit. supra note 13, at 133 .

${ }^{27}$ Ibid.

${ }^{28} \mathrm{KEETON}$, op. cit. sutpra note $\mathrm{I} 7$, at 142.

${ }^{20}$ Id. at 140; JACKSON, MACHINERY OF JUSTICE IN ENGLAND 227 (1953).

${ }^{30} I d$. at 116 .
} 
The Home Secretary appoints a Director of Public Prosecutions who works under the general supervision of the Attorney General. ${ }^{31}$ It is the Director's duty to prosecute the graver offenses such as murder punishable by death and cases referred to him by government departments if in his opinion such prosecutions are proper and present undue difficulty or importance. ${ }^{32}$ We are told, however, that neither the Director nor the Attorney General of England is concerned with criminal investigation, detection, collection of evidence, and apprehension, these being matters for the police and other agencies. ${ }^{33}$ In this country, these investigatory activities, when related to federal laws, fall within the jurisdiction of the Federal Bureau of Investigation, which is within the Department of Justice.

In this country, the Attorney General alone is responsible for prosecuting violations of federal law. Any attempt by other members of the President's Cabinet or anyone else to influence the exercise of his responsibility might be viewed as an improper interference with the course of impartial justice. This is the rule, too, in England in ordinary circumstances, but where political offenses are involved such as sedition, it is said not to be uncommon for the Cabinet to consider the question of prosecution. ${ }^{34}$

While the primary responsibility for prosecuting violations of federal law belongs to the Attorney General, the actual conduct of these proceedings is generally carried on in various regions of the country by United States Attorneys and their stafts, all of whom are under the supervision of the Attorney General and report to him. The extent of their enforcement activities is indicated by the fact that for the fiscal year 1959, roughly $\$ 32,500,000$ was collected for the United States Treasury, about 56,100 cases were filed in the federal courts, and about 55,500 cases terminated. ${ }^{35}$

In connection with law enforcement in this country, a difficult question that frequently arises because of the dual form of government is whether the federal or state authorities have jurisdiction of a case. The borderline that separates one from the other is often obscure and makes for confusion in the public mind when neither federal nor state authori-

\footnotetext{
${ }^{31} I d$. at $\times 14$.

${ }^{33}$ Ibid.

${ }^{33} \mathrm{Id}$. at $1 \times 5$.

${ }^{34}$ Jennings, op. cit. supra note 19, at 236. But see RadCliffe \& Cross, The ENGLISH LEgAL SYSTEM 398 ( 3 d ed. r954).

${ }^{35}$ Statistics furnished by Mr. Bain, Administrative Office, Department of Justice.
} 
ties take action to redress a wrong or where both assert authority to the exclusion of the other.

But in England, too, there are jurisdictional problems. This point was made by Jackson in his book The Machinery of Justice in England, when he said: ${ }^{36}$

... if a question relates to say criminal or civil procedure it is by no means clear to whom the question should be addressed. In the Commons the Home Secretary may well say that it is not his business. The AttorneyGeneral will probably say that it is not his business, perhaps adding that he will communicate with the Lord Chancellor. In the House of Lords the Lord Chancellor may intimate that it is not his responsibility, but that the matter will be considered.

However, apparently some of these problems arise from the absence of a centralized department of justice.

Although the United States Department of Justice handles all criminal litigation and substantially all civil litigation in the federal courts, it should be noted that almost every executive department or agency has its own legal staff and advisers. They perform valuable housekeeping functions, enforce administrative orders, and by express statute may be authorized to conduct their own litigation by injunction and other suits and to handle appeals in lower courts. However, the Attorney General, assisted by the Solicitor General, has the ultimate responsibility for all government litigation that reaches the Supreme Court regardless of who handled it in a lower court. Unlike Attorneys General in our early history, the Attorney General of the United States today rarely appears personally even in the most important litigation in the Supreme Court, although he has the right to do so-and, in fact, did so this term in one significant case involving civil rights. As a rule, this is the principal function and business of the Solicitor General and his staff. As a practical matter, an Attorney General who attempted to prepare for a trial of great public interest, or argument on complicated issues in the Supreme Court, would have little time left to discharge his duties as legal adviser to the President and department heads, and to administer the many other duties and functions of his office. ${ }^{37}$

\footnotetext{
${ }^{36} \mathrm{~J}_{\text {ACKSON, }}$ op. cit. supra note 29 , at $34^{2}$.

${ }^{37}$ See James, op. cit. supra note 21 at 27 . But see Mason, Harlan Fiske Stone 167-74 (1956), which indicates that Stone revived the tradition under which Attorneys General argued cases for the Government. In the last fifteen years, few court appearances have been made by them.
} 
Another major difference between the two offices is that the Attorney General of the United States heads a major department of the Government, with vast administrative functions, whereas the duties of his counterpart in England are, for the most part, not administrative. ${ }^{38}$

The English Attorney General, for example, has no responsibility for penal institutions, which are administered by the Home Secretary. ${ }^{39}$ The Attorney General of the United States, on the other hand, has direct responsibility for the federal prison system. Again, it is the Home Secretary, who in England has power to order the deportation of an undesirable alien. ${ }^{* 0}$ In our country, administrative proceedings looking to this end, as well as immigration and naturalization matters generally, are under the Attorney General. In England, it is the custodian of enemy property in whom enemy private property is vested. ${ }^{41}$ In our country, this function falls within the administrative machinery of the Office of Alien Property, a division of the Department of Justice. In England, clemency is exercised on the advice of the Home Secretary. ${ }^{42}$ Here, it is the Attorney General who makes recommendations to the President on applications for executive clemency. Recommendations to the President for the selection of all federal judges are also matters within the jurisdiction of our Attorney General. The English Attorney General has no comparable duties in the formal sense, judicial appointments being made on recommendation of the Prime Minister and the Lord Chancellor; ${ }^{43}$ but no doubt the views of the Attorney General would carry great weight with the Prime Minister or Lord Chancellor.

As busy as an Attorney General may be in this country, it would seem that his schedule is no more difficult than that which besets an Attorney General of England. In his autobiography, Sir Patrick Hastings described the devastating legal and political problems of his office in a manner that would almost discourage any one else from ever aspiring to it. He wrote: ${ }^{44}$

${ }^{38} \mathrm{JenNings,} \mathrm{op.} \mathrm{cit.} \mathrm{supra} \mathrm{note} 19$, at 59 .

${ }^{30} \mathrm{KEITH}$, op. cit. supra note $\mathrm{r}_{3}$, at $2 \mathrm{x}_{3}$; WADE \& PHILLIPs, op. cit. supra note $x_{3}$, at 248 .

${ }^{10} I d$. at 200.

${ }^{41}$ Id. at 201 .

${ }^{2} I d$. at 245 .

${ }^{43}$ Schuster, The Ofice of the Lord Chancellor, 1o CAMB. L. J. 175, 177-79 (1949); JENNINGS, op. cit. sipra note 19 , at 453-54.

"The Autoblography of Sir Patrick Hastings 236 (undated). Compare Wirt's experiences as Attorney General of the United States, as described in Cummings \& MCFARLAND, op. cit. sutpra note 9, at 89 . 
. My day began at seven o'clock in the morning and I rarely got to bed before five the next morning. The day was spent in one long rush between the Law Courts, Government departments, and the House of Commons. The night, or rather the early morning, was needed in order to get ready for the next day. Nothing that I began was I ever allowed to finish; and nothing was ever finished until something else was begun. Being an AttorneyGeneral as it was in those days is my idea of hell. The only person who enjoyed my exalted position was my chauffeur. As $I$ was in possession of a Cabinet pass I was authorized to drive through the streets without any regard to ordinary police regulations. He invariably elected to cross Trafalgar Square on the wrong side.

While there are many variations, both great offices have one common bond that transcends all else. In each case, it is not that the Government shall win a case, but that justice shall be done its citizens in the courts. Thus it is that in both countries, adherence to untarnished traditions and principles tends as nearly as possible to assure freedom under law for all. 